\title{
Pembelajaran Kreatif Berbasis Student Centered Learning pada Elektronika Dasar I Melalui Model Problem Based Learning
}

\author{
${ }^{1}$ Muh. Makhrus, ${ }^{2}$ Wahyudi \\ ${ }^{1,2}$ Program Studi Pendidikan Fisika, PMIPA, Universitas Mataram, Jl. Majapahit 62 \\ Mataram, Indonesia 83125 \\ Email: makhrus.fkip@unram.ac.id
}

\begin{tabular}{|c|c|}
\hline Arti & stract \\
\hline $\begin{array}{l}\text { Article History } \\
\text { Received: 05 Feb } 2020 \\
\text { Revised: } 05 \text { Mei } 2020 \\
\text { Published: } 30 \text { June } 2020\end{array}$ & \multirow{2}{*}{$\begin{array}{l}\text { This study aims to measure the ability of soft skills and hard skills of students } \\
\text { after attending Elementary Electronics learning through creative learning } \\
\text { based on student-cantered learning with problem-based learning models. } \\
\text { Research subjects in this study were } 25 \text { students of the physics education } \\
\text { program University of Mataram. This type of research is a qualitative } \\
\text { descriptive and assessment of the ability of soft skills and hard skills carried } \\
\text { out by } 2 \text { observers based on the assessment of soft skills and hard skills } \\
\text { assessment instruments when learning Elementary Electronics is ongoing. } \\
\text { Based on the results of the study, learning Basic Electronics I based on student } \\
\text { centered learning with problem based learning models combined with the use } \\
\text { of livewire } 1.1 \text { Pro including learning that can increase student activity. This } \\
\text { learning can increase student soft skills and hard skills up to } 85 \% \text { which is } \\
\text { included in the very high category }\end{array}$} \\
\hline $\begin{array}{l}\text { Key } \\
\text { Cre } \\
\text { stuc } \\
\text { lean } \\
\text { lear } \\
\text { har }\end{array}$ & \\
\hline Inf & 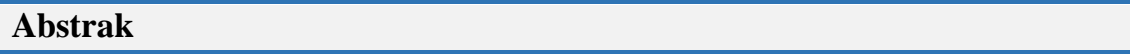 \\
\hline $\begin{array}{l}\text { Sejarah } \\
\text { Diterima: } \\
\text { Direvisi: } \\
\text { Dipublika }\end{array}$ & \multirow{2}{*}{$\begin{array}{l}\text { Penelitian ini bertujuan untuk mengukur kemampuan soft skill dan hard skill } \\
\text { mahasiswa setelah mengikuti pembelajaran Elektronika Dasar I melalui } \\
\text { pembelajaran kreatif berbasis student centered learning dengan model problem } \\
\text { based learning. Jumlah subyek uji pada penelitian ini sebanyak } 25 \text { mahasiswa } \\
\text { program studi pendidikan fisika Universitas Mataram. Jenis penelitian ini } \\
\text { adalah deskriptif kualitatif dan penilaian terhadap kemampuan soft skill } \\
\text { maupun hard skill dilakukan oleh } 2 \text { orang pengamat berdasarkan instrumen } \\
\text { penilaian soft skill dan hard skill pada saat kegiatan pembelajaran Elektronika } \\
\text { Dasar I sedang berlangsung. Berdasarkan hasil penelitian, pembelajaran } \\
\text { Elektronika Dasar I berbasis student centered learning dengan model problem } \\
\text { based learning dipadu dengan penggunaan software livewire 1.1 Pro termasuk } \\
\text { pembelajaran yang mampu meningkatkan keaktifan mahasiswa. Pembelajaran } \\
\text { ini mampu meningkatkan soft skill dan hard skill mahasiswa sampai dengan } \\
85 \% \text { yang termasuk dalam kategori sangat tinggi. }\end{array}$} \\
\hline $\begin{array}{l}\text { Kat } \\
\text { Pem } \\
\text { stua } \\
\text { mod } \\
\text { lear } \\
\text { har }\end{array}$ & \\
\hline
\end{tabular}

Sitasi: Makhrus, M., \& Wahyudi, W. (2020). Pembelajaran Kreatif Berbasis Student Centered Learning pada Elektronika Dasar I Melalui Model Problem Based Learning. Kappa Journal. 4 (1), 23-30

\section{PENDAHULUAN}

Pendekatan pembelajaran yang berpusat pada mahasiswa atau yang biasa dikenal dengan istilah Student Centered Learning (SCL) merupakan proses pembelajaran yang mengutamakan pengembangan kreativitas, kapasitas, kepribadian, dan kebutuhan mahasiswa, serta mengembangkan kemandirian dalam mencari dan menemukan pengetahuan. Pendidikan tinggi diharapkan mengambil peran dalam menghasilkan lulusan yang kompeten dengan kualifikasi yang cocok dengan tantangan yang dihadapi bangsa Indonesia. Pendidikan tinggi harus mampu secara tepat mengidentifikasi kebutuhan di lingkungannya dan menyiapkan proses pembelajaran yang menjamin lulusannya dapat menjawab tantangan tersebut. Dalam rangka meningkatkan kualitas lulusan yang siap kerja, pendidikan tinggi dituntut untuk dapat 
mengembangkan berbagai pendekatan SCL. Pendekatan SCL yang paling sering diterapkan pada pendidikan tinggi melalui proses pembelajaran dengan menggunakan model pembelajaran berbasis masalah (problem based learning). Melalui penerapan model pembelajaran tersebut diharapkan secara simultan dapat meningkatkan baik kompetensi soft skill maupun hard skill mahasiswa.

Adapun kompetensi soft skill dan hard skill mahasiswa yang dimaksud adalah seperti pada Tabel 1 berikut.

Tabel 1. Kompetensi soft skill dan hard skill mahasiswa

\begin{tabular}{|c|c|c|}
\hline No & Kompetensi Soft Skill & Kompetensi Hard Skill \\
\hline 1 & Ketakwaan dan akhlak mulia & Kemampuan dalam memahami konsep \\
\hline 2 & Tanggung jawab di kelompok diskusi & $\begin{array}{l}\text { Kemampuan mengenali fitur-fitur dalam } \\
\text { software livewire 1.1 Pro }\end{array}$ \\
\hline 3 & Kreatifitas dalam pemecahan masalah & $\begin{array}{l}\text { Kemampuan dalam menggunakan software } \\
\text { livewire } 1.1 \text { Pro untuk menggambar } \\
\text { rangkaian diode }\end{array}$ \\
\hline 4 & Kemampuan analitis dan berpikir kritis & $\begin{array}{l}\text { Ketepatan dalam menggambar rangkaian } \\
\text { diode dengan kesesuaian konsep yang terkait } \\
\text { dengan penyearah gelombang }\end{array}$ \\
\hline 5 & Kemampuan komunikasi & \multirow{6}{*}{$\begin{array}{l}\text { Kemampuan dalam menterjemahkan } \\
\text { parameter-parameter terkait dengan materi } \\
\text { penyearah gelombang berdasarkan isyarat } \\
\text { keluaran yang dihasilkan dari rangkain } \\
\text { diode. }\end{array}$} \\
\hline 6 & Kemandirian & \\
\hline 7 & $\begin{array}{l}\text { Sikap keterbukaan (open minded) pada } \\
\text { saat berdiskusi }\end{array}$ & \\
\hline 8 & Sikap demokratis & \\
\hline 9 & $\begin{array}{l}\text { Sikap toleran dan adaptif terhadap } \\
\text { lingkungan }\end{array}$ & \\
\hline 10 & Kompetitif & \\
\hline
\end{tabular}

Pemilihan pendekatan pembelajaran yang sesuai dengan tujuan kurikulum dan potensi mahasiswa merupakan kemampuan dan ketrampilan dasar yang harus dimiliki oleh seorang dosen. Sistem pembelajaran di perguruan tinggi saat ini masih berjalan secara tradisional dan menghambat mahasiswa untuk dapat belajar secara aktif dan kreatif. Sistem pembelajaran dengan pendekatan tradisional tidak cukup untuk menghasilkan lulusan yang kompeten, terutama untuk bidang-bidang tertentu seperti sains dan teknologi. Pembelajaran yang berpusat pada mahasiswa atau student centered learning (SCL) dapat membuat mahasiswa memperoleh kesempatan untuk membangun pengetahuannya sendiri, sehingga akan memperoleh pemahaman yang mendalam yang pada akhirnya dapat meningkatkan pemahaman konsep mahasiswa. Hesson (2007: 628) menjelaskan bahwa SCL model is teaching integrative thinking, based on existing models of creativity and synthesis. In this model, the student is put at the heart of a bigger learning process that includes instructors, specialists and the public.

Pada pendekatan SCL, berarti mahasiswa harus didorong untuk memiliki motivasi dalam diri sendiri kemudian berupaya keras mencapai kompentensi yang diinginkan. Hal ini dapat dilakukan dengan cara memperbanyak waktu berdiskusi, sehingga mahasiswa mampu dan berani mengemukakan pendapat. Harapannya dengan diterapkan pendekatan SCL, maka mahasiswa dapat berpartisipasi secara aktif, memiliki daya kritis, mampu menganalisa dan dapat memecahkan permasalahan. Ide dasar dari student-centeredness adalah student might not only choose what to study, but how and why that topic might be an interesting one to study (O’Neill dan McMahon, 2005). SCL merupakan pendekatan pembelajaran yang menempatkan mahasiswa sebagai subyek/peserta didik yang aktif dan mandiri, dengan 
kondisi psikologik sebagai adult learner, bertanggung jawab sepenuhnya atas pembelajarannya, serta mampu belajar beyond the classroom.

Antika (2014), menyatakan bahwa pembelajaran berbasis Student Centered Learning menuntut murid aktif, serta melakukan diskusi dengan guru sebagai fasilitator jika menemui kesulitan. Aktifnya siswa diharapkan mampu menumbuhkan rasa kreativitas siswa. Ramadhani (2017) juga mengatakan, Pendekatan SCL cukup efektif karena memberikan ruang kebebasan dan kesempatan kepada peserta didik untuk menggali sendiri ilmu pengetahuannya dengan banyak sumber referensi yang dapat ia akses sehingga nantinya mahasiswa akan mendapat pengetahuan yang jauh lebih mendalam (deep learning) dan mampu meningkatkan kualitas mahasiswa.

Pembelajaran berbasis masalah atau Problem based learning (PBL) mampu membuat mahasiswa berperan aktif dalam pembelajaran. Fauzan (2017) mengatakan model PBL mampu menumbuh kembangkan kemampuan mahasiswa dalam mengidentifikasi masalah, kemampuan menyimpulkan hasil serta ketrampilan mengelola waktu. Model ini juga menambah pemahaman dan keterampilan mahasiswa dalam menyampaikan pendapat dan gagasan-gagasannya di depan kelas. Abdurrozak dkk (2016) mengatakan PBL merupakan sebuah pembelajaran yang menuntut siswa untuk mengkonstruksi pengetahuan mereka sendiri melalui permasalahan.

Kegiatan pembelajaran ini dilakukan dengan cara melaksanakan pembelajaran dengan menggunakan model pembelajaran berdasarkan masalah atau problem based learning (PBL), di mana mahasiswa aktif mengkonstruksi pengetahuan dan menyelesaikan permasalahan yang diberikan dengan cara aktif mengakses informasi dan pengetahuan secara online baik yang diupload dosen maupun dari internet dan menggunakan program livewire 1.1 pro yaitu software yang dapat digunakan untuk menggambar rangkaian elektronika dan menghasilkan grafik keluaran yang dapat digunakan untuk menentukan besarnya parameter-parameter terkait seperti pada praktikum sebenarnya untuk menyelesaikan permasalahan yang diberikan dosen.

\section{METODE}

\section{Jenis Penelitian dan Subyek Uji}

Jenis penelitian ini adalah penelitian kualitatif. Subyek uji pada penelitian ini adalah mahasiswa program studi Pendidikan Fisika mata kuliah Elektronika Dasar I PMIPA FKIP Universitas Mataram.

\section{Instrumen dan Analisis Data}

Kemampuan soft skill dan hard skill mahasiswa setelah mengikuti perkuliahan dengan penggunaan program livewire melalui model PBL pada mata kuliah elektronika dasar I diukur dengan menggunakan instrumen penilaian kemampuan soft skill dan kemampuan hard skill mahasiswa. Persentase besarnya kemampuan soft skill dan hard skill mahasiswa, diperoleh dari nilai akhir kemampuan x 100\%. Nilai akhir adalah jumlah skor/jumlah deskriptor tiap kemampuan soft skill dan hard skill yang dimiliki mahasiswa pada saat pembelajaran.

Tabel 2. Kriteria kemampuan soft skill dan hard skill

\begin{tabular}{ll}
\hline Kategori & Persentase \\
\hline Rendah & $0-25$ \\
Sedang & $25<\mathrm{P} \leq 50$ \\
Tinggi & $50<\mathrm{P} \leq 75$ \\
Sangat Tinggi & $75<\mathrm{P} \leq 100$ \\
\hline & \multicolumn{1}{c}{ (Makhrus, 2018) }
\end{tabular}


Reliabilitas hasil pengamatan oleh kedua pengamat dilakukan dengan menggunakan "Interobserver" dengan analisis statistik "Percentage of Agreement" yaitu:

Percentage of Agreement $=100 \%\left(1-\frac{A-B}{A+B}\right) \quad$ (Borich, 1994:385)

Instrumen lembar respons mahasiswa digunakan untuk mengetahui tanggapan atau pendapat mahasiswa terhadap model pembelajaran yang telah dilakukan dan perangkat pembelajaran pendukung model. Mahasiswa memberikan penilaian atau pendapat dengan cara memberikan tanda cek $(\sqrt{ })$ pada kolom yang tersedia sesuai dengan pertanyaanpertanyaan yang mencakup penilaian terhadap pembelajaran dengan menggunakan model PBL dibantu dengan software livewire untuk menggambar rangkaian elektronika. Data hasil respons mahasiswa terhadap pembelajaran dianalisis secara deskriptif dengan cara menjumlahkan tiap skor penilaian yang diberikan seluruh mahasiswa untuk setiap aspek yang dinilai. Jumlah tiap skor penilaian tersebut kemudian di rerata secara keseluruhan untuk semua aspek sehingga diperoleh persentase respons mahasiswa untuk tiap kategori penilaian. Kategori penilaian yang diberikan mahasiswa adalah (1) tidak baik, (2) kurang baik, (3) baik, (4) sangat baik.

\section{HASIL DAN PEMBAHASAN}

\section{Hasil}

Berdasarkan analisis data hasil pengamatan terhadap kemampuan soft skill dan hard skill mahasiswa pada saat proses pembelajaran diperoleh hasil sebagai berikut.

Tabel 3. Kemampuan Soft Skill dan Hard Skill Mahasiswa

\begin{tabular}{lccccc}
\hline \multicolumn{1}{c}{ Matakuliah } & Skill & $\begin{array}{c}\text { Jumlah } \\
\text { Mahasiswa }\end{array}$ & $\begin{array}{c}\text { Rata-rata } \\
\text { nilai }\end{array}$ & Persentase & Kategori \\
\hline Elektronika & Soft skill & 25 & 3,35 & 83,75 & Sangat tinggi \\
\cline { 2 - 6 } Dasar I & Hard skill & 25 & 3,12 & 78,00 & Sangat tinggi \\
\hline
\end{tabular}

Hasil penilaian di atas menunjukkan bahwa rata-rata kemampuan mahasiswa dalam kategori sangat tinggi. Rata-rata persentase kemampuan soft skill maupun hard skill berkisar antara 76\%-85\%. Secara lebih detail dapat dilihat pada Gambar 1 dan Gambar 2.

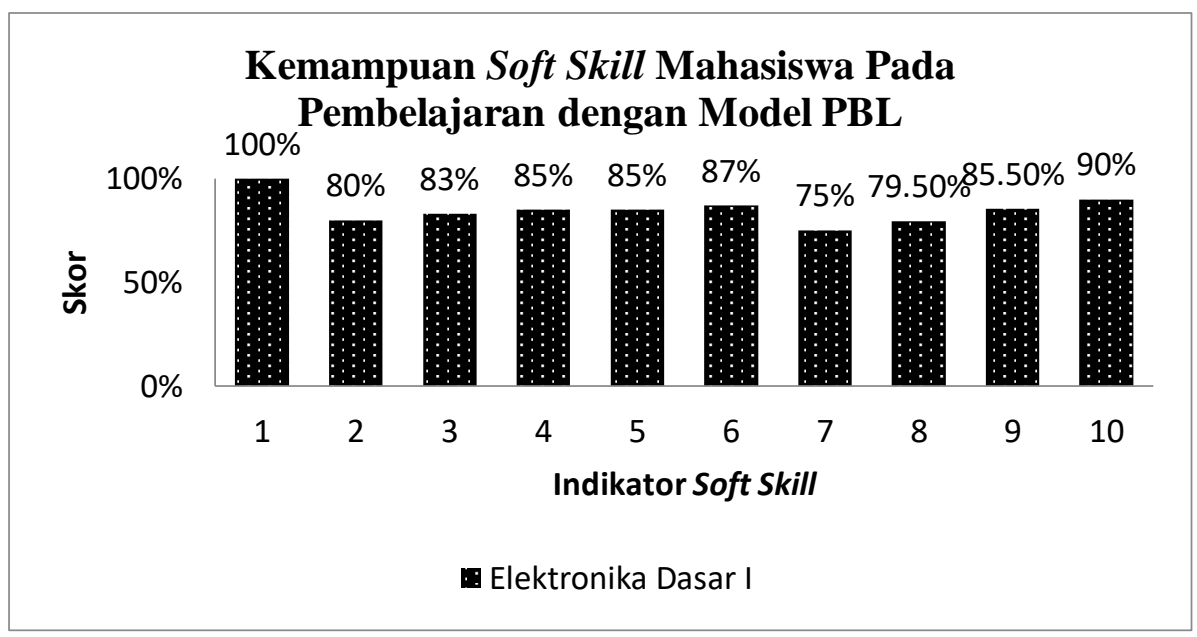

Gambar 1. Persentase soft skill per indikator

Keterangan indikator: 1. Ketakwaan dan akhlak mulia; 2. Tanggung jawab di kelompok diskusi; 3. Kreatifitas dalam pemecahan masalah; 4. Kemampuan analitis dan berpikir kritis; 5. Kemampuan komunikasi; 6. Kemandirian; 7. Sikap keterbukaan (open minded) pada saat 
berdiskusi; 8. Sikap demokratis; 9. Sikap toleran dan adaptif terhadap lingkungan; 10. Kompetitif

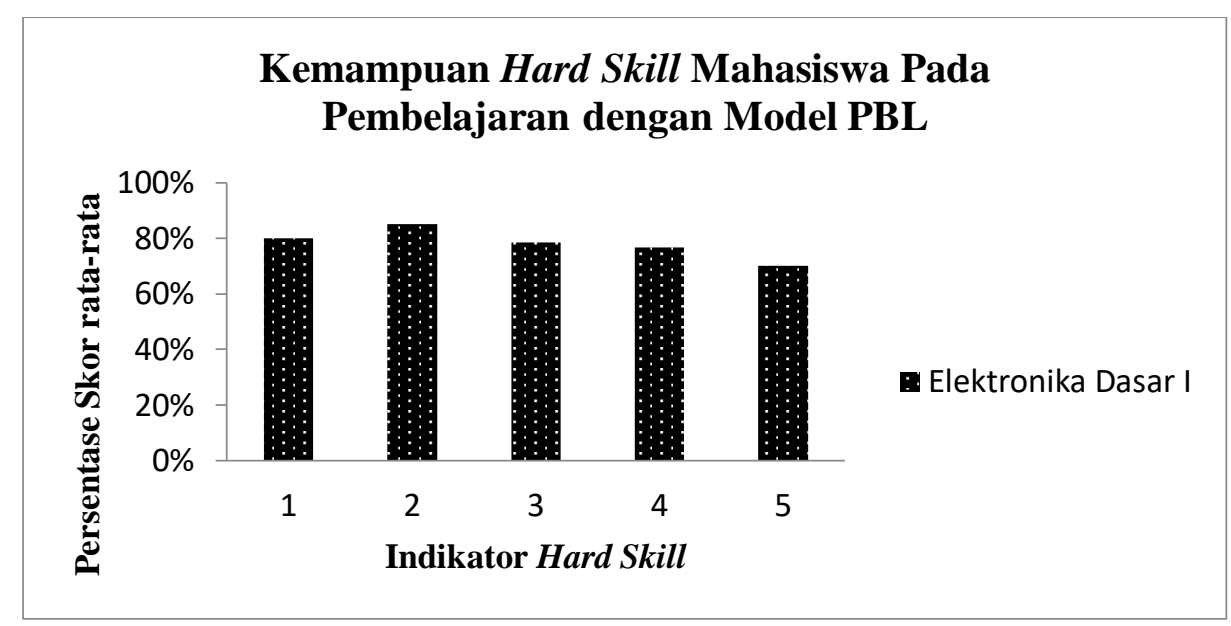

Gambar 2. Persentase Hard Skill tiap indikator

Keterangan Indikator: 1. Kemampuan dalam memahami konsep; 2. Kemampuan mengenali fitur-fitur dalam software livewire 1.1 Pro; 3. Kemampuan dalam menggunakan software livewire 1.1 Pro untuk menggambar rangkaian diode; 4. Ketepatan dalam menggambar rangkaian diode dengan kesesuaian konsep yang terkait dengan penyearah gelombang; 5. Kemampuan dalam menterjemahkan parameterparameter terkait dengan materi penyearah gelombang berdasarkan isyarat keluaran yang dihasilkan dari rangkain diode.

Berdasarkan Gambar 1 dan Gambar 2, terlihat persentase tiap indikator termasuk dalam kategori sangat tinggi dan tinggi. Fakta ini membuktikan bahwa pembelajaran dengan PBL mampu meningkatkan soft skill dan hard skill mahasiswa dengan persentase berkisar antara 75\%-100\% untuk soft skill dan 70\%-85\% hard skill.

Fakta ini membuktikan bahwa pembelajaran PBL termasuk dalam pembelajaran kreatif yang mampu menumbuhkan soft skill maupun hard skill mahasiswa sehingga pembelajaran menjadi lebih efektif yang pada akhirnya dapat meningkatkan pemahaman konseptual mahasiswa tentang materi Elektronika Dasar I.

Berdasarkan data hasil pengamatan oleh dua orang pengamat dengan menggunakan instrumen pengamatan terhadap kemampuan soft skill dan hard skill mahasiswa pada saat pembelajaran, diperoleh koefisien reliabilitas instrumen pengamatan seperti pada Tabel 4 berikut ini.

Tabel 4. Koefisien reliabilitas instrumen pengamatan kemampuan soft skill dan hard skill mahasiswa

\begin{tabular}{lc}
\hline Pengamatan terhadap & Koefisien Reliabilitas $(\%)$ \\
\hline Dosen & 98,11 \\
\hline Mahasiswa & 97,96 \\
\hline
\end{tabular}

Berdasarkan Tabel 4 di atas menunjukkan bahwa koefisien reliabilitas rata-rata instrumen pengamatan lebih besar dari 75\%, sehingga instrumen tersebut termasuk dalam kategori instrumen yang baik (Borich, 1994). Dengan demikian instrumen pengamatan ini dapat digunakan pada pelaksanaan pembelajaran selanjutnya. 


\section{Pembahasan}

Pembelajaran Elektronika Dasar I dengan melalui model pembelajaran PBL dengan dipadu penggunaan software livewire 1.1 Pro diawali dengan cara menyampaikan tujuan pembelajaran yang mengarah pada permasalahan yang harus diselesaikan oleh mahasiswa. Mahasiswa membentuk kelompok diskusi dalam menyelesaikan permasalahan yang diberikan oleh dosen dan menyampaikan hasil diskusi kelompoknya di depan kelas. Mahasiswa dari kelompok lain memberikan pertanyaan dan tanggapan terhadap hasil presentasi tersebut. Di akhir pembelajaran, dosen memberikan penguatan materi terhadap permasalahan yang telah didiskusikan agar mahasiswa mendapatkan pengetahuan yang utuh terkait dengan materi pembelajaran.

Penilaian terhadap kemampuan soft skill dan hard skill mahasiswa pada saat kegiatan pembelajaran dilakukan oleh dua orang pengamat. Hasil penilaian menunjukkan bahwa kemampuan mahasiswa dalam kategori baik. Aspek yang sering dinilai cukup baik oleh kedua pengamat adalah untuk kemampuan soft skill adalah pada saat berdiskusi umumnya masih didominasi oleh beberapa mahasiswa saja, artinya sikap keterbukaan (open minded) pada saat berdiskusi (banyak memperoleh kesempatan berbicara, mengeluarkan pendapat, bertanya kepada dosen/mahasiswa) masih kurang. Pada kemampuan hard skill untuk mata kuliah Elektronika Dasar 1, pengamat melihat kemampuan mahasiswa adalah dalam kategori baik dan sangat baik, tetapi untuk kemampuan dalam menggunakan Livewire 1.1 Pro untuk membuat gambar dan kemampuan dalam menterjemahkan parameter-parameter terkait dengan materi penyearah gelombang berdasarkan isyarat keluaran yang dihasilkan dari rangkain diode diberikan penilaian cukup baik. Fakta ini mendukung penelitian sebelumnya dari Ardian dan Munadi (2015) yang mengatakan pendekatan SCL berarti mahasiswa harus didorong untuk memiliki motivasi dalam diri sendiri kemudian berupaya keras mencapai kompentensi yang diinginkan. Hal ini dapat dilakukan dengan cara memberikan waktu lebih banyak untuk berdiskusi, maka mahasiswa akan lebih berani untuk mengemukakan pendapat, belajar memecahkan masalah yang dihadapi dan tidak takut pada dosen.

Pembelajaran dengan pendekatan SCL dengan menggunakan menggunakan Livewire 1.1 Pro akan memberikan kesempatan kepada mahasiswa dalam merefleksi hasil dan proses pemecahan masalah, memberikan penguatan dan umpan balik terhadap konsep yang diperoleh melalui investigasi, dan memberikan kesempatan kepada mahasiswa untuk bertanya. Mahasiswa juga memiliki kesempatan untuk mengakomodasi sebuah pandangan, konsep-konsep atau skill-skill baru kemudian memperluas konsep tersebut dengan cara mengaplikasikan dan membuat hubungan antara konsep baru atau skill dengan situasi-situasi dan gagasan-gagasan lain berdasarkan gambar rangkaian diode yang telah dibuat dengan menggunakan software livewire 1.1 Pro. Pembelajaran Visual dapat pula menumbuhkan minat mahasiswa dan dapat memberikan hubungan antara isi materi pelajaran dengan dunia nyata atau kontekstual (Munandar dkk. 2018).

Hasil pengamatan terhadap kemampuan soft skill dan hard skill mahasiswa juga selaras dengan hasil analisis respon mahasiswa terhadap pembelajaran melalui model pembelajaran PBL dengan dipadu penggunaan software livewire 1.1 Pro serta perangkat pembelajaran pendukung model yang digunakan dalam pembelajaran. Berdasarkan analisis hasil respon dapat diketahui bahwa persentase mahasiswa yang memberikan penilaian dalam kategori sangat baik jauh lebih besar daripada mahasiswa yang memberikan penilaian dalam kategori cukup baik dan baik, bahkan tidak ada mahasiswa yang memberikan penilaian dalam kategori tidak baik. Hasil analisis di atas menunjukkan bahwa pembelajaran yang dilakukan pada mata kuliah Elektronika Dasar I dapat dilaksanakan dengan sangat baik dalam pembelajaran di kelas. Mahasiswa umumnya merasa senang dengan kegiatan pembelajaran yang dilakukan dengan menggunakan software livewire 1.1 Pro, karena memberikan pengalaman baru tentang penggunaan software dalam membantu kegiatan pembelajaran. 
Keaktifan mahasiswa dilibatkan sejak awal proses pembelajaran dalam bentuk desain belajar yang memperhitungkan aspek pengetahuan, keterampilan, dan pengalaman belajar mahasiswa yang telah didapatkan sebelumnya (O’Neill dan McMahon, 2005: 28).

Pembelajaran SCL dengan model PBL sangat efektif dalam menumbuhkan soft skill dan hard skill mahasiswa. Firmansyah dkk. (2015) mengatakan bahwa PBL merupakan model pembelajaran yang memberikan kesempatan peserta didik menggali pengalaman autentik sehingga mendorong mereka aktif belajar, mengkonstruksi pengetahuan, dan mengintegrasikan konteks belajar di sekolah dan kehidupan nyata secara ilmiah. Hal ini dapat dilihat pada persentase hasil soft skill dan hard skill yang termasuk dalam kategori tinggi dan sangat tinggi. Data ini juga didukung oleh hasil wawancara dan angket yang diberikan kepada mahasiswa. Berdasarkan hasil wawancara, mahasiswa berpendapat bahwa pembelajaran dengan SCL memberikan stimulus/rangsangan terhadap mahasiswa yang membuat mereka lebih aktif dalam proses pembelajaran. Pembelajaran SCL ini juga memberikan kemudahan pada mahasiswa untuk mencari materi dan memahami materi yang diberikan oleh dosen pengampu. Hasil penelitian ini sejalan dengan pendapat Harsono (2008) yang mengatakan pembelajaran SCL memiliki karakteristik sebagai berikut: (a) pebelajar dewasa yang aktif (mentally not physically), interaktif, mandiri, bertanggung jawab atas pembelajarannya, mampu belajar beyond the classroom, dan memiliki jiwa pembelajar sepanjang hayat, (b) adanya keleluasaan bagi para mahasiswa untuk mengembangkan segenap potensinya, mengeksplorasi dan mentransformasi ilmu pengetahuan, (c) pembelajaran yang bersifat kolaboratif, kooperatif dan kontekstual, (d) alih fungsi dosen dari sumber utama ilmu pengetahuan menjadi fasilitator yang menerapkan "Patrap Tri Loka" secara utuh.

\section{KESIMPULAN}

Berdasarkan hasil penelitian dapat disimpulkan bahwa : 1) pembelajaran SCL dengan metode PBL mampu meningkatkan keaktifan mahasiswa; 2) pembelajaran SCL dengan metode PBL mampu menumbuhkan soft skill dan hard skill mahasiwa hingga $85 \%$ yang termasuk dalam kategori sangat tinggi.

\section{SARAN}

Penelitian ini baru sampai tahap menumbuhkan soft skill dan hard skill mahasiwa pada saat pembelajaran berlangsung berkaitan dengan penggunaan program Livewire 1.1 Pro melalui pembelajaran PBL. Saran bagi penelitian lanjutan untuk memadukan penggunaan program Livewire 1.1 Pro dalam pembelajaran Elektronika Dasar dengan eksperimen langsung di laboratorium, sehingga mahasiswa dapat mengetahui langsung parameterparameter yang terukur dari penggunaan program Livewire 1.1 Pro memiliki kesamaan atau tidak dengan hasil eksperimen.

\section{UCAPAN TERIMA KASIH}

Penelitian ini terselenggara berkat rahmat dari Allah SWT dan bantuan dari berbagai pihak, terutama dari Lembaga Penelitian dan Pengabdian kepada Masyarakat dan Program Studi Pendidikan Fisika FKIP Universitas Mataram. Bersama ini kami tim peneliti mengucapkan terima kasih atas segala bantuan dan kerjasamanya.

\section{DAFTAR PUSTAKA}

Abdurrozak, R., Jayadinata, A.K., \& Isrok'atun. (2016). Pengaruh Model Problem Based Learning Terhadap Kemampuan Berpikir Kreatif Siswa. Jurnal Pena Ilmiah, 1(1), 871-880.

Antika, R.R. (2014). Proses Pembelajaran Berbasis Student Centered Learning (Studi Deskriptif di Sekolah Menengah Pertama Islam Baitul 'Izzah, Nganjuk. Bio-Kultur, 3(1), 251-263. 
Ardian, A. \& Munadi, S. (2015). Pengaruh Strategi Pembelajaran Student-Centered Learning Dan Kemampuan Spasial Terhadap Kreativitas Mahasiswa. Jurnal Pendidikan Teknologi dan Kejuruan, 22(4), 454-466.

Borich, D. (1994). Observation skills for effective teaching. Englewood Cliffs: Macmillan Publishing Company.

Fauzan, M., Gani, A., \& Syukri, M. (2017). Penerapan Model Problem Based Learning Pada Pembelajaran Materi Sistem Tata Surya Untuk Meningkatkan Hasil Belajar Siswa. Jurnal Pendidikan Sains Indonesia, 5(1), 27-35.

Firmansyah, A., Kosim, \& Ayub, S. 2015. Pengaruh Model Pembelajaran Berbasis Masalah dengan Metode Eksperimen pada Materi Cahaya Terhadap Hasil Belajar Fisika Siswa Kelas VIII SMPN 2 Gunungsari Tahun Ajaran 2014/2015. Jurnal Pendidikan Fisika dan Teknologi, 1(3):154-159.

Harsono. (2008). Student-Centered Learning di Perguruan Tinggi. Jurnal Pendidikan Kedokteran dan Profesi Kesehatan Indonesia, 3(1), 4-8.

Hesson, M., and Shad, K.F. 2007. A Student-Centered Learning Model. American Journal of Applied Sciences. 4 (9), 628-636.

Makhrus, (2018). Peranan Konflik Kognitif terhadap Perubahan Konseptual Pada Mahasiswa tentang Konsep Gaya. Jurnal Fisika dan Pendidikan Fisika KONSTAN, 3(1), 1-8.

Munandar, H., Sutrio, dan Taufik, M. (2018). Pengaruh Model Pembelajaran Berbasis Masalah Berbantuan Media Animasi terhadap Kemampuan Berpikir Kritis dan Hasil Belajar Fisika Siswa SMAN 5 Mataram Tahun Ajaran 2016/2017. Jurnal Pendidikan Fisika dan Teknologi, 4(1), 111-120.

Ramadhani, H.S. (2017). Efektivitas Metode Pembelajaran Scl (Student Centered Learning) Dan Tcl (Teacher Centered Learning) Pada Motivasi Instrinsik \& Ekstrinsik Mahasiswa Psikologi Untag Surabaya Angkatan Tahun 2014-2015. Jurnal Psikologi Indonesia, 6(2), 66-74.

O'Neill, G., and McMahon, T. 2005. Student-Centred Learning: What Does It Mean for Students and Lecturers? Dalam O' Neill, G., Moore, S. \& McMullin, B. (Eds.). Emerging Issues in the Practice of University Learning and Teaching (27-36). Dublin: AISHE 